This item was submitted to Loughborough's Research Repository by the author.

Items in Figshare are protected by copyright, with all rights reserved, unless otherwise indicated.

\title{
'An instruction in good citizenship': Scouting and the historical geographies of citizenship education
}

PLEASE CITE THE PUBLISHED VERSION

http://dx.doi.org/10.1111/j.1475-5661.2012.00500.x

\section{PUBLISHER}

Blackwell Publishing $@$ The Author. Transactions of the Institute of British Geographers $@$ Royal Geographical Society (with the Institute of British Geographers)

\section{VERSION}

AM (Accepted Manuscript)

\section{LICENCE}

CC BY-NC-ND 4.0

\section{REPOSITORY RECORD}

Mills, Sarah. 2019. "'an Instruction in Good Citizenship': Scouting and the Historical Geographies of Citizenship Education”. figshare. https://hdl.handle.net/2134/12149. 
This item was submitted to Loughborough's Institutional Repository (https://dspace.lboro.ac.uk/) by the author and is made available under the following Creative Commons Licence conditions.

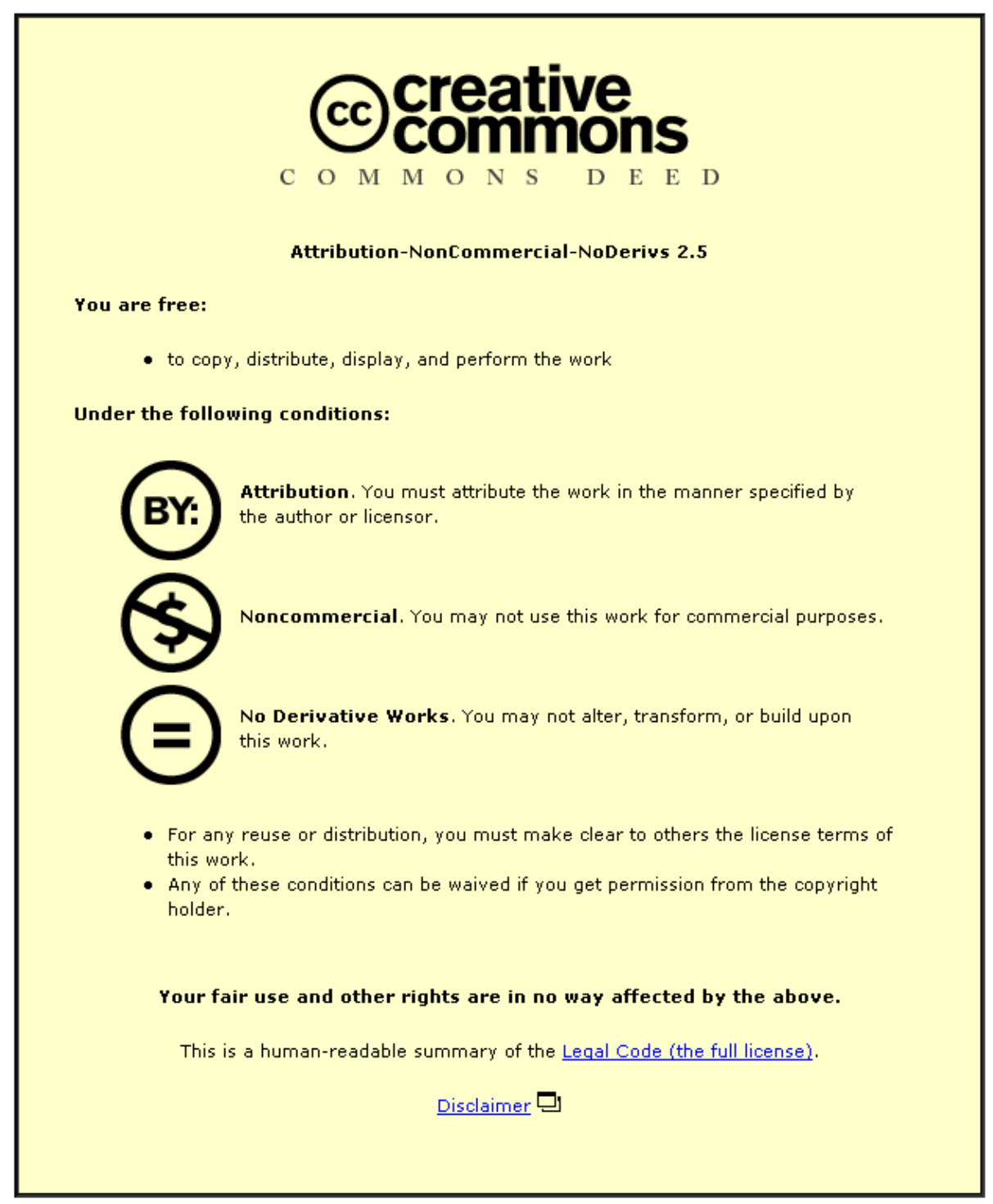

For the full text of this licence, please go to: http://creativecommons.org/licenses/by-nc-nd/2.5/ 


\title{
"An Instruction in Good Citizenship": Scouting and the Historical Geographies of Citizenship Education
}

\author{
Sarah Mills, Department of Geography, Loughborough University
}

To cite this paper:

Mills, S. (2013) "An Instruction in Good Citizenship": Scouting and the Historical Geographies of Citizenship Education, Transactions of the Institute of British Geographers 38 (1): $120-134$

\section{Introduction}

In July 2010, the coalition government of the UK announced its plans for a 'National Citizen Service' (NCS) - a flagship initiative for its 'big society' vision. The NCS includes taskbased learning, volunteering and summer camps designed to support young people "to develop the skills and attitudes they need to get more engaged with their communities and become active and responsible citizens” (Cabinet Office 2010). The citizenship-based rhetoric and activities of the NCS, launched in Summer 2011 and expanded through pilot schemes in 2012, resonates with long-standing ideas about young people as 'citizens-in-themaking' and their required 'training'. The interest in formal state-led citizenship education in Britain has waxed and waned throughout the last century, with the NCS forming the latest rebranded scheme. However, these ideas have been embedded in the rationale and pedagogical methods of various other arenas of informal education as part of Britain's voluntarist tradition, with uniformed youth movements in particular having consistently held citizenship as their central motif and raison d'être.

This paper examines informal citizenship training for youth and the historical geographies of education over time through analysing the Scout Movement in Britain and its activities in the first half of the twentieth century. In exploring the cultural and historical 
geographies of youth citizenship through scouting, this paper makes three distinct contributions to current debates in human geography as well as extending understandings of youth movement spaces outside of the discipline.

Firstly, this paper contributes to the burgeoning literature on geographies of citizenship, and in particular, on youth citizenship. Thus far, geographers exploring young people’s recent experiences of citizenship education (Pykett 2009; Weller 2007) and the historical landscapes of citizenship, pedagogy and nationhood (Gruffudd 1996; Ploszajska 1996, 1998) have all focused on school environments (for a review of geographical research on schools, see Collins and Coleman 2008). Furthermore, political historians and scholars in education studies examining the flux in state interest in civics over time have also centred their research on formal education (Heater 2001; Jeffs 2005). This paper therefore seeks to extend this work through examining one example of an alternative arena where youth citizenship was enacted and mobilised - the Scout Movement. Other historical geographical research (Matless 1995, 1998; Merriman 2005) has highlighted the various spaces and mechanisms through which young people were introduced to ideas of (rural) citizenship such as the Youth Hostels Association and the Country Code. However, these studies are small in number and there remains a dearth of work on the different spaces in civil society where ideas on citizenship were communicated to youth and the role of practices and spatialities in the performance of citizenship education. This paper emerges from these concerns and highlights how youth movements can offer a lens through which to view changing conceptions and understandings of where young people 'fit' in society. Here, I examine the emergence and transformation of particular political-cultural formations associated with British youth and citizenship, grounded in a case-study analysis of the organisational spaces of the Scout Movement, founded in Britain by Robert Baden-Powell in 1908. In focusing on one uniformed youth movement - a volunteer organisation designed by adults for young 
people and structured in age-range sections across national and international networks - this paper interrogates how scouting was originally conceived, emerged and operated as a key social site for the production of knowledge(s) and meaning(s), as well as how its practices and discourses have been central in understanding its (re)production of certain citizensubjects over the last century. With particular emphasis on the way what I term an ideal 'citizen-scout' was originally constructed, and how good and bad behaviour was codified in a series of moral geographies and group-making projects, I show how young people were cast as both 'citizens-in-the-making' - preparing them for adult citizenry - as well as being given a distinct set of responsibilities as 'active citizens' whilst Scouts. The key contribution of this paper is therefore to interrogate how, over time, attempts have been made in various sites and settings in civil society to mobilise young people into distinct youth citizenship formations and position them as governable citizen-subjects.

Second, this paper offers a rare and much-needed historical contribution to literature within children's geographies (although see Gagen 2000, 2004). This contribution is significant; indeed, whilst a now well-established sub-discipline in contemporary human geography, attention to the ways in which children have been constructed, positioned and experience space and place over time has been hitherto neglected. In this analysis, I want to draw attention to how notions of 'goodness' and 'morality' in terms of model (young) citizens are geographically and historically situated. These ideas are important - especially as tracing how they emerged over time can illuminate and inform debates on youth in contemporary society. Indeed, questions over whether young people are 'living up' to the roles laid out for them by various actors, or going in the right 'direction', are pervasive and children's geographers have reflected on these expectations and the moral geographies of modern childhoods in various contexts (Valentine 1996; Katz 2008). In this paper, I want to highlight how a historical perspective can enhance such studies through considering the shifts 
in these ideas over time. Furthermore, there are significant motivations in considering the historical geographies of youth citizenship as current political debates on civic education schemes (such as those described in the opening paragraph) have renewed vigour in contemporary Britain. This paper’s historical examination can, therefore, begin to attend to such debates and expand children’s geographies in new and relevant directions.

Third, in utilising a specific methodological strategy, this article makes a contribution to the historical geographies of materiality and embodiment and literature on historical research practice (Gagen et al. 2007; Lorimer 2009). In taking embodied historical geographies seriously (Griffin and Evans 2008), I reflect on how scouting was accomplished through particular practices, and significantly, materialities. This approach helps to illuminate the actual doing of scouting and its citizenship training project.

In terms of this paper's contribution outside of geography, this research builds upon and extends studies of the Scout Movement in the discipline of history (Proctor 2002, 2009; Warren 1986). These have examined scouting and its biographical key players in detail, but have not fully considered the role of materialities, embodied practise and performance in its organisational spaces. Other studies of British youth movements by historians have been comparative and focused on class, demographics and political ideology (Springhall 1977; Wilkinson 1969), whilst scholars in education studies are beginning to examine how political and religious beliefs feature in spaces of youth work (Rose 2005). A geographical approach could therefore provide a more complete picture of the ways in which youth movement's communicated their unique citizenship projects to members. More substantially, it can offer a unique insight into the spaces, practises and performances that enabled the training schemes of youth movements, as well as the various roles they continue to play in the lifeworlds of children and young people. 
I begin this paper by reviewing debates on the geographies of youth citizenship and the historical geographies of education. I then introduce the Scout Movement and its specific 'place' within the landscape of British youth work. The remainder of the article provides a detailed analysis of the construction and maintenance of 'citizen-scout'. Here, I explore the specific ways in which a moral geography of behaviour and culture of scouting were used to sustain a specific vision of future British citizenry, before offering some reflections on the reenvisioning of 'citizen-scout' in the concluding remarks.

\section{'Learning to be Citizens': Geographies of Youth Citizenship}

In his seminal work on citizenship, T. H. Marshall stated that "children, by definition, cannot be citizens" and positioned them as “citizens-in-the-making” (1950, 25). This exclusionary position has been internalised by many state-level approaches to youth and fed into wider discourses about how to ‘deal with’ young people. As well as a time of socialisation into 'adulthood', young people are also seen as needing to learn how to be citizens in the future. There is an implicit understanding here that not only is knowledge about citizenship essential for a rational adult individual, but that the process is pedagogical (as opposed to experiential) and must be learnt as a child. This is further complicated as citizenship is differentially understood, indeed it is a highly contested concept in geography and the social sciences more broadly (Isin 2002; Desforges et al. 2005). Sociologist Ann Mische describes how:

[citizenship] functions simultaneously as a claim to rights, a call for participation and a carrier for competing social projects...it is within such highly mobile and politicised fields of shifting meanings and relationships that young people carry out the difficult work of 'learning to be citizens'. $(1996,158)$

This challenge for young people is shaped by (adult) questions concerning what kind of citizen young people ought to become, or conversely, what type of (uncivil) citizen they 
would become if not guided in the 'correct' way. As part of a wider moral landscape of childhood (Valentine 1996), therefore, a number of schemes have institutionalised the learning process Mische describes - including the Scout Movement.

Youth citizenship is inherently complex due to the ambiguity and conflicting status of when childhood 'stops' and adulthood 'begins' (James 1986; Valentine 2003). Indeed, whereas children under eighteen have some of the rights of citizenship such as protection of particular freedoms under state and international law, they are not old enough to access all the legal, social and political rights of citizens that T. H. Marshall outlined, for example the right to vote. Social scientists have explored how this fragmented experience and issues of autonomy create problems for young people (Cockburn 1998) and how they often construct their own understandings and methods of participation during this period of transition (Thomson et al. 2004). The notion of 'active citizenship' is pertinent here in that young people (in predominantly Western societies) often find themselves paradoxically encouraged to become 'active' citizens whilst in this temporary phase and therefore feel some of the expectations and responsibilities of being a citizen. This is an important conceptual point; although active citizenship has been discussed by political geographers as the product of British Conservative Governments in the late 1980s and early 1990s (Kearns 1992, 1995), there has been a lack of research on the historical geographies of active citizenship and the emergence and transformation of this concept over time. This paper attends to these concerns, illustrating how active citizenship (and by extension 'passive' citizenship) were at the heart of Baden-Powell’s scheme.

I contend that the primary objective of the Scout Movement has been to train and guide youth into adult citizenry, whilst at the same time, fixing a 'proper place' for children in the present where their behaviour could be governed and they could contribute (both individually and collectively) through an emasculated version of citizenship. The rationale 
behind scouting is explored shortly, and whilst the role of gender in scouting is not the focus of this paper (see Mills 2011a), it is worth highlighting here how specific gendered constructions were important in an organisation that sought to create an ideal British boyhood of citizens (on masculinities, see Van Hoven and Hörschelmann 2005).

\section{Historical Geographies of Citizenship Education}

This section expands upon earlier references to literature on citizenship education and discusses in more detail how young people have been encouraged to 'become' good citizens through various spatial tactics and formations. On the one hand, historical geographers have explored the role of education in broader state projects of nation-building and imperial imaginations. For example, Teresa Ploszajska has examined how both model-building (1996) and geography fieldwork (1998) featured in English schools during the late nineteenth and early twentieth century and Pyrs Gruffudd (1996) has outlined the role of outdoor education in Welsh schools during the inter-war period. Both examples demonstrate how ideas about the empire or nation were subtle parts of school curriculums, drawing attention to how institutional spaces designed for young people were fused with broader discourses about belonging and identity. On the other hand, researchers studying the contemporary geographies of education (Mitchell 2003; Hanson Thiem 2009) have drawn attention to the complex, politicised and often citizenship-based restructuring of educational spaces. Of particular interest are geographical studies on the compulsory inclusion of citizenship education in English schools since 2002. Susie Weller (2007) and Jessica Pykett (2009) have explored young people's experiences of these lessons in the Isle of Wight and Bristol respectively, stressing the links between participation, civic engagement and belonging in contemporary discourses of citizenship education. Researchers outside of geography, primarily in education studies, have contextualised the 2002 policy shift through tracing the 
relatively low emphasis on formal civic education in Britain in the past (Heater 2001; Jeffs 2005).

Both these sets of literature on historical and contemporary educational settings in relation to citizenship, however, have focused primarily on the school. As I introduced earlier, ideas on youth citizenship are not limited to these formal structures and there has been a lack of research on citizenship training in alternative spaces. A notable exception is Elizabeth Gagen's historical research on identity construction through US playgrounds (2000) and how child psychology featured in ideas about physical education, character development and subject formation taken up by urban reformers during the early twentieth century (2004). This paper attempts to move this literature on through looking at a scheme of citizenship training in Britain that emerged and operated in civil society, and in doing so, illustrates how competing and shifting conceptions of 'good' citizenship are played out and refracted in both the state and civil society's activities.

This broader relationship between the state and civil society has been explored by political geographers (for example, Painter 2006) and outside the discipline. Notably, political scientist Michael Freedman has traced this relationship through examining philosophies of citizenship over the course of the twentieth century, arguing that "the various attempts to combine the two [state and civil society], or to make one of them decisively trump the other, merely serve to emphasize that they still coexist in an unresolved but arguably healthy tension” (2003, 275). A geographical approach to youth movements could enhance such discussions through fleshing out how political ideologies revolving around citizenship were translated to youth in practice, as well as how space and embodied practices have been crucial in the performance of citizenship education. 
Early formats of informal citizenship training for youth emerged in Britain in the late nineteenth and early twentieth century through boys' and girls’ clubs, religious schemes and youth movements such as Salford Lads Club in Lancashire (1903), Jewish youth club 'Victoria' in East London (1901) and the Boys' Brigade in Scotland (1883, see Kyle 2007). These were established and run by adult volunteers as part of a distinct voluntarist tradition in Britain; indeed, volunteering has its own complex relationship with citizenship (Milligan and Fyfe 2005). In these spaces, subtle yet sustained messages about behaviours and attributes of a 'good' citizen (or Christian, Jew, worker) could be repeated on a regular basis as part of adventurous and exciting programmes for youth. In many ways, the state played 'catch-up' in providing a youth service. Whilst it had introduced a series of education acts from as early as 1870, state-apparatus attempted to regulate and shape the voluntary sector by creating organised bodies to support voluntary work, for example the British Youth Council in 1948 (Davies 1999). Youth clubs, organisations and movements were often brought together under the umbrella heading of 'volunteer youth work', however, each type of scheme was unique in terms of their philosophies and geographical expressions.

The emergence of uniformed youth movements in Britain can be seen in a broader context of European youth movements, many of whom have notorious reputations due to their links with fascism. For example, the German Youth Movement which ran from 19011945 was composed of several parts with shifting political influences, its most famous splinter being HitlerJugend formed in 1922 (Stachura 1981). In Britain, youth movements varied in terms of political and religious identity, but all had an overarching primary concern with manufacturing 'young British citizens' in line with some vision or particular code of living to create a future efficient and useful body of adult citizenry. Most youth movements, including the Boys’ Brigade (1883), Scout Movement (1908) and Woodcraft Folk (1925), are still active today and form part of a much broader and increasingly professionalised voluntary 
youth service sector in Britain. What is important to note is that, over time, all youth movements have advertised the direction they believed their young members were heading in and made claims over their role in shaping the youth of the nation into particular types of citizen. Indeed, youth movements utilise and prioritise the liminal period of youth as a critical and necessary stage in the lifecourse in which to harness and secure an individual's (future) potential and political capital for their cause(s).

\section{Methodology}

This paper is concerned with how one such scheme - the Scout Movement - functioned as a site for the production of particular sets of knowledge and meanings, in this case around citizenship. The material presented in this paper is taken from archival research at the collections of the Scout Association, housed at their National Headquarters in Gilwell Park, Essex - a historic estate which also functions as a running camp site and visitor activity centre. I contend that children's geographers could better utilise archival methods and historical research for a number of reasons: first, to access material that can be used to trace how particular organisations understood childhood and their role in relation to youth (protection, regulation, education); second, to make space for children’s 'voices' (either written or in oral histories) that give a first-hand account of their experiences at particular points in time; and finally, to garner accounts of children’s agency (Gagen 2001), resistance and transgression that could invert the representational politics of the archive.

A number of historians and historical geographers have stressed the need for researcher's to consider the politics of the archive, its stewards and the construction of particular types of knowledge (Lorimer 2009; Moore 2010). In this research there was an interesting tension between Gilwell Park’s role in preserving the organisation’s history and its contemporary day-to-day function in developing scouting in the UK. In many ways, the 
organisation seeks to promote a fresh and relevant 'brand image' and distance itself from the old-fashioned stereotypes that haunt the organisation; yet on the other hand, it acknowledges and draws upon aspects of history (role in wartime Britain, anniversaries, famous ex-scouts) for various public relation and financial reasons. Furthermore, the role and place of the archives within the Scout Association is a relatively recent event. The material, along with new offices for the Scout Association staff, was moved into a renovated Gilwell Park in 2001 as a deliberate attempt to combine Scout history with the contemporary movement. It was therefore important to consider the archive as part of the process that I am concerned with on the ways in which this organisation has functioned and maintained a youth citizenship project.

The majority of the collection is printed material (records, census data, correspondence, minutes, publications, draft documents, memorandum, reports and policy documents spanning its centennial history), but I also draw on other 'texts'. These include a series of junior scout novels and magazines published by the organisation. I have chosen to specifically use the fictional texts cited in this paper as they illustrate explicit attitudes to youth at particular points in time, as well as being popular and classic examples of the genre. These were part of the archival collection, although other junior fiction novels were accessed via eBay, a form of data collection that has its own ethical and methodological issues (DeLyser et al. 2006).

The archival collection at Gilwell Park also contained paintings, illustrations, uniforms, badges, flags, toys and other memorabilia. I draw upon these objects to illustrate the embodied historical geographies of scouting (Griffin and Evans 2008) and to explore how scouting ideology was communicated to members through learning materials. Indeed, the material traces of objects and their appropriation by young people are presented in this article as a useful way to examine the original youth citizenship project of scouting in Britain. 


\section{'Our Future Citizenhood': Duty to Self, Others and God}

Robert Baden-Powell's conceptualisation of scouting began during his service in the Boer War (1899-1902) where he witnessed young boys assisting soldiers with small observation tasks - or 'scouting' (Jeal 1991). His method was developed as a scheme for youth over a number of years through public lectures and correspondence and he piloted his methods in August 1907 at a camp on Brownsea Island, Dorset. Following the camp, Baden-Powell refined his method and published Scouting for Boys: A Handbook for Instruction in Good Citizenship in May 1908 as a series of magazine supplements that would become the original blue-print of scouting (Boehmer 2004).

The Chief Scout was motivated by a number of class-based Edwardian anxieties about the state of the nation and future of the British Empire. The Boer War in particular had exposed the physical weaknesses of the British Army and raised fears about the possible decline of Britain's imperial power if left in the hands of unhealthy and lacklustre (workingclass) male youth (Warren 1986; see also Gagen 2004 for US example). Scouting was promoted as being able to 'stem the tide' and we can see here how youth is often mobilised as a powerful national metaphor for hope in the face of anxieties, insecurities and unknown possible futures (Katz 2008; Kraftl 2008).

Baden-Powell's scheme aimed to develop the physical, mental and spiritual life of the boy on the road to adulthood through outdoor education and training in woodcraft. The sheer popularity of scouting at a grassroots level meant that 'The Boy Scouts Association' (hereafter BSA) was officially formalised in $1908 .{ }^{1}$ Age-based guidelines were established for Scouts (approx. 10-15), with sections for younger and older boys introduced in due course. Its sister movement - the Girl Guides - was founded in 1910 and has its own 
genealogical development (Proctor 2009). Scouting quickly expanded from Britain to its imperial and Commonwealth nations, and further afield, with the establishment of the World Organisation of the Scout Movement (WOSM) in 1920, and it is currently the largest youth organisation in the world with over two hundred national organisations.

Citizenship has consistently featured as the central aim of the Scout Movement during the last century. Baden-Powell sustained the belief, with conviction, that through scouting young people in Britain (and abroad) could become better citizens:

The aim of the Scout training is to improve the standard of our future citizenhood, especially in Character and Health; to replace Self with Service, to make the lads individually efficient, morally and physically, with the object of using that efficiency for service for their fellow-men. (Baden-Powell [1944] 1919, 33-4, original emphasis)

Here, citizenship was attached to the notion of 'character', a popular idea in early twentieth century Britain entwined with stirring masculinist qualities (Freeden 2003). Baden-Powell believed scouting would "turn the rising generation on the right road for good citizenship" (2004 [1908], 297) and in directing them on this journey, he provided clear examples of good citizenship for youth to emulate, rather than merely offering negative critiques. In Scouting for Boys, he told adventurous stories of the Knights of King Arthur, the Crusaders and Capt. John Smith, describing these men of empire as ‘scouts of the nation' (2004 [1907], 13), and intermeshed these heroic tales of patriotism with practical training in outdoor skills (Phillips 1997). The Chief Scout mounted a direct challenge to his young readership and called for a return to a clean manliness, a moral geography of values inscribed on the body in order to restore the nation's strength and create 'citizens of empire’ (Warren 1986).

Baden-Powell’s youth citizenship model and methodology was clearly articulated in his early texts and revolved around three parts: duty to self, duty to others and duty to God. 
Duty to self focused on ideas of self-discipline and a regulation of the self, as he explained:

A man who can control himself, his anger, his fear, his temptations - everything, in fact, except his conscience and his shame - that man is well on the way to being a gentleman (Baden-Powell 1922a, 84)

This notion of the regulated self-governed subject ties into broader debates on subjectification and conduct (Rose 1996; Foucault 1988) and in particular, on the position of youth as governable citizen-subjects. Indeed, one could see the ideology of scouting - with BadenPowell stressing "self-control not only enables you to master bad habits, but also gives you command of your very thoughts” (1922a, 86) - as an early form of self-governance that predates neoliberal forms of governing at a distance (Cobb 2007; Merriman 2005). The second tenet of Baden-Powell's citizenship model - 'duty to others' - referred to a Scout's responsibilities for his local neighbours, fellow Britons and imagined 'others' of the Empire, embodied in the practise of doing a 'good turn' (explored later in the paper). Finally, the third strand of Baden-Powell's model - duty to God - involved attaining the status of a future 'citizen of heaven'. Religion has always been a contentious issue within scouting, and yet an element of faith was seen by the Chief Scout as an essential part of a Scout's obligation. The spiritual aspect of scouting's brand of citizenship is unique, particularly as Baden-Powell stressed an individual's obligation to practice their own belief and for leaders to accommodate non-Christian members, thus complicating the stereotype of the organisation as Christian (Mills 2009).

These three elements - duty to self, others and God - express a utilitarian concept of citizenship whereby Scouts are universalised as individuals working for the 'greater good' (Wittemans 2009). I would also argue that there were two separate projects in action: firstly, to encourage Scouts to develop as self-regulated and duty-bound individuals; and secondly, 
to create a collective body of Scouts and unite them through a sense of belonging. Members were united through ritualised and symbolic practices such as the Scout salute, sign and left handshake - cultures of embodied movement. These corporeal markers were an insider's prized knowledge and are just one example of how a sense of belonging and inclusion between members was generated. Furthermore, the concept of duty at all three levels (self, other, God) was seen as a series of embodied practices. One example of this is the Scout motto 'Be Prepared', which Baden-Powell explained meant "you are always to be in a state of readiness in mind and body to do your DUTY” (2004 [1908], 44). We can again see ideas of disciplining the self here as he continued:

Be prepared in Mind by having disciplined yourself to be obedient in every order, and also by having thought out beforehand any accident or situation that might occur, so that you know the right thing to do at the right moment, and are willing to do it. Be prepared in Body by making yourself strong and active and able to do the right thing at the right moment, and do it. (Baden-Powell 2004 [1908], 44, original emphasis)

'Be Prepared' was therefore communicated as an anticipatory embodied practice, rather than just a mere slogan. This aspect of scouting philosophy also hints at the responsibilities afforded to Scouts as active citizens. On the one hand, Baden-Powell believed that boys who participated in his scheme would be well-rounded and good citizens as future adults. But, crucially, he believed Scouts also had an important role to play as young citizens whilst belonging to the organisation, stressing that "Passive citizenship is not enough. Only active citizenship will do" (1944 [1919], 16-18, original emphasis). These notions were central to Baden-Powell's educational philosophy and were embedded in the everyday skills learnt and performed by Boy Scouts. Camping, hiking, cooking, cleaning and crafting were regular parts of the scout programme and these types of skills and practices demonstrated the characteristics that scouting authorities felt Scouts needed in order to 'do their duty'. 
Pedagogical Methods and the 'Medicine' of Scouting

In terms of the pedagogy of scouting, early troops met weekly and self-taught from Scouting for Boys. Over time, adult leaders were approached and Scout Huts were built or appropriated to function as a regular space of learning in villages, towns and cities. Scouters (adult volunteers in scouting) were seen as 'experts' that disseminated knowledge to youth 'on the ground' and generated senses of citizenship, most powerfully in the countryside (Gruffudd 1996; Matless 1995, 1997). A Scouter's role was influential as they were the regular figure in a Boy Scout's life, in contrast to the heroic but ultimately out-of-reach Chief Scout. Scouters were formally trained by the BSA and made aware of their important role, expressed here in an illustration from one of Baden-Powell's handbooks:

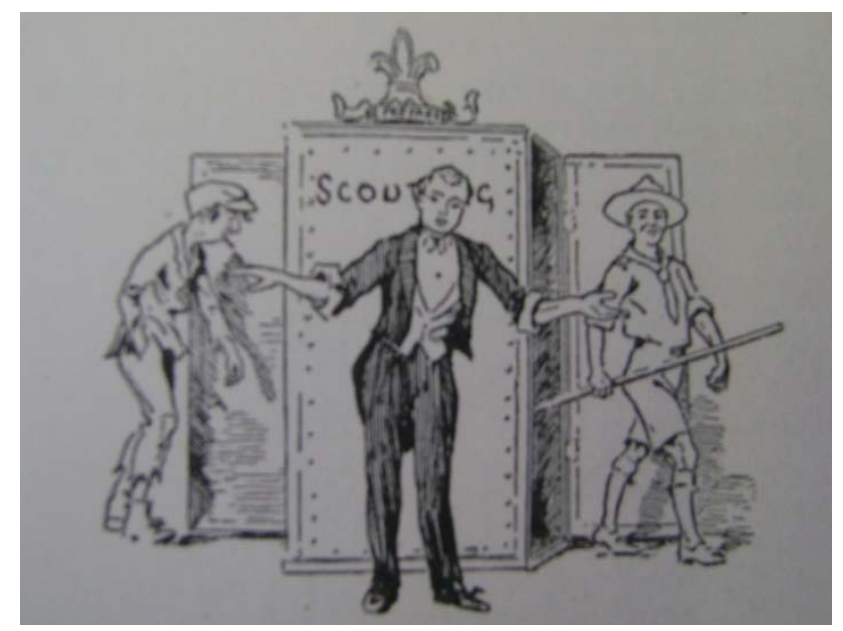

Plate 1: 'The Scoutmaster's conjuring trick'

Source: Baden-Powell 1933, 283

Acting on behalf of Baden-Powell, Scouters would perform the 'trick' of turning an unkempt and unhealthy individual into a proud, clean and upright Scout, man and citizen. They were also seen as ultimately responsible for the success of scouting, with the founder stressing: 
Scouting is a medicine composed of various ingredients and, unless they are mixed in their proper proportions according to the prescription, the users must not blame the doctor if the effects on the patient are unsatisfactory. (Baden-Powell 1922b)

Scouters were accountable, then, for 'mixing' this 'prescription' for British youth at a grassroots level.

Individual scouts were also responsible for their own development and behaviour. I explore this in more detail in the next section, but one example that shows how Scouts were encouraged to be self-governing individuals is the Charles Letts Boy Scout Diary. With pages to record parade attendance, height and weight, as well as maps to Gilwell Park and extracts from Scouting for Boys, the diary was intended to encourage Scouts to structure their weeks around scouting events and camping seasons. Fifteen year old Eric Holl from Brighton used his Scout diary from 1929 in this way, recording:

January $2^{\text {nd }}$ : Scouts social at 7.30. Had games, tea and music. Had prizes. January $30^{\text {th }}$ : Staves parade at Scouts. Bought one $1 \mathrm{~d}^{2}$

In the memorandum pages, Eric had listed the members of his patrol, and significantly, used the diary in a regulatory sense to list absentees, recording on the $9^{\text {th }}$ February - "all patrol there except Stan". ${ }^{3}$ It could be argued, therefore, that material objects such as this enabled the messages of scouting to gain wider circulation and instilled practices of self-governance in (young) citizens (Merriman 2005).

Having outlined the rationale and philosophy of scouting, I now want to move on to specifically discuss how an ideal 'citizen-scout' was constructed by the organisation and maintained by a series of moral geographies embodied in the practices of Boy Scouts. Here, I combine ideas from both fiction and real-life accounts of scouting in Britain, as both feed into how an ideal 'model' Boy Scout was envisioned by the organisation. 


\section{Constructing Citizen-Scout and the Moral Geographies of Scouting}

Outside Gilwell Park is a replica of the 1937 sculpture The Boy Scout by R. Tait McKenzie donated by the Boy Scouts of America in 1966 (Plate 2). Also known as The Ideal Scout, this statue is an emblematic symbol of the iconic member of the Scout Movement.

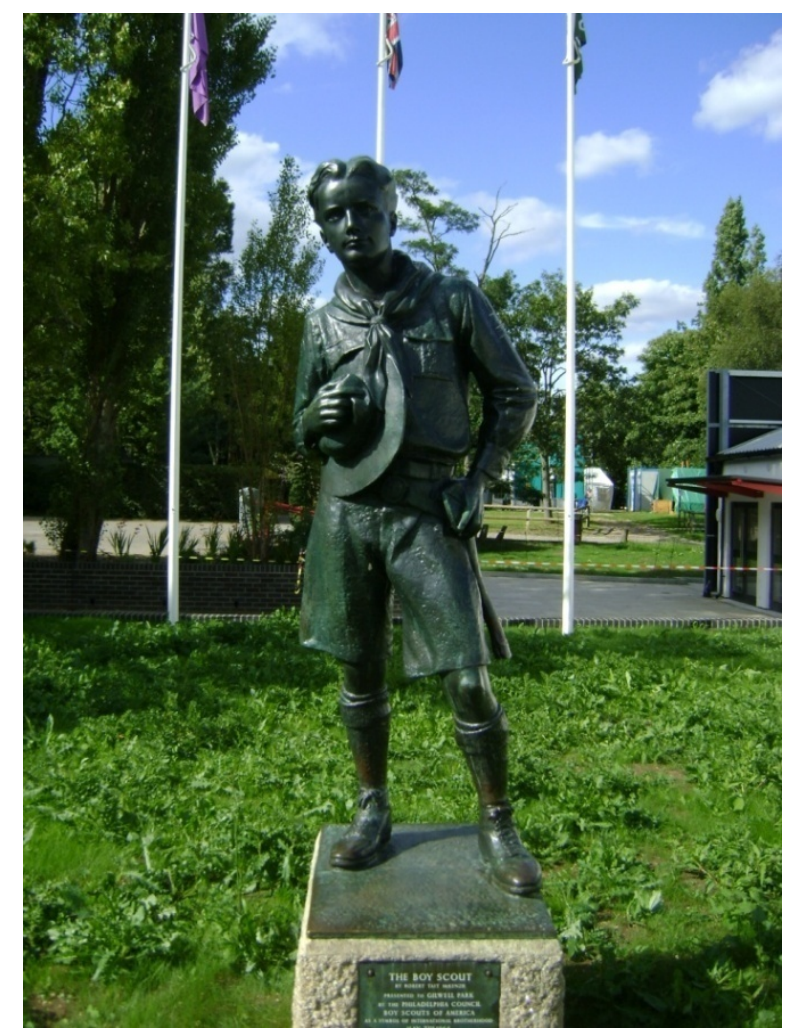

Plate 2: The Boy Scout, Gilwell Park, Essex

Source: Author's photograph

The statue depicts a young, physically able and uniformed male youth - characteristic of the ideal scouting citizen Baden-Powell envisioned and the early parameters of membership that immediately positioned some young people (such as girls) as incompatible, despite the 'opento-all' overtone of Scouting for Boys. 'Citizen-scout' had a particular appearance, but also personality traits and characteristics that chimed with Baden-Powell's vision. He would be adventurous, brave, and fit in mind and body - a certain 'type' of boy. These desirable traits 
were often communicated by the organisation (and other publishing houses) through novels and films about fictional Boy Scouts’ solving crimes and assisting the police, including Peter Lawson, Wolf-Cub or the Mystery of Redcroft Farm (Davidson 1926), Rivals of Parnham (Dimmock 1939) and Boy Scouts - Be Prepared! (dir. Boy Scouts Association 1917).

Baden-Powell also visualised scouting's target audience as a specific type of youth 'in need' of scouting. This approach was infused with ideas about social class and the ability of middle and upper class youth to 'instruct' working class youth by example and instruction in 'good citizenship'. The organisation's understandings of 'youth in need' have shifted over time from the original demographic of the entire national (male) youth population following the stasis of the Boer War, to other conceptualisations of 'troublesome' and 'deviant' youth as potentially transformable characters. Indeed, this highlights how the concept of youth 'subcultures' has a much longer trajectory than its association with post-war Britain (Savage 2007). One example of this visualisation of scouting's target audience can be seen in how young people were represented in junior scout novels. In these stories, non-Scouts were usually cast as troublesome bodies, for example boys who belonged to gangs. They were presented as reformable characters with the potential for good if they joined their local Scout Troop. For example, F. Hayden Dimmock’s (1939) Rivals of Parnham concerns a Scout Troop plagued by Dizzy Watkins' troublesome gang, and the dilemma of new-boy Pierre. Pierre eventually chooses to join Dizzy's gang rather than the Troop, a fact that troubles Dennis - model citizen-scout - who "can’t think why he mixes with Dizzy Watkins and his gang' (Dimmock 1939, 14). In some extracts, the reader can sense an almost evangelical urgency about trying to encourage others to become Scouts, with Dennis talking in his sleep how he "Must get him [Pierre] to join the Troop...make a fine Scout... Make him a Scout...tells grand yarns...knows a lot about Woodcraft...must be a Scout” (Dimmock 1939, 15). There is also a recurring moralistic theme based around social class in these 
novels through examples of reformed characters that have been 'saved' by scouting. A clear illustration is Scout Family Robinson, Dimmock’s last published novel:

The Robinsons are a very happy family with a keen interest in the Scout and Guide Movements...But it is when the family go on a caravan camping holiday, taking with them a boy who has been in trouble with the Police and is on probation, that we see the Robinsons at their best...he too finds happiness in serving others. (Dimmock 1954, inside sleeve)

This mission-like attempt to reform a juvenile boy through scouting is emblematic of later fears surrounding troublesome youth and draws on many of the specific moral panics over youth sub-cultures in post-war Britain (Cohen 1973; Hall and Jefferson 1976).

The maintenance of an ideal 'citizen-scout' was enabled through distinctive moral geographies that reinforced ideological behaviours, bodies and environments, often drawing upon powerful notions of self and Other (Driver 1988; Cresswell 1996). A number of geographers have explored the ways in which improved citizenship involves conforming to a set of 'good' behaviours and practices. David Matless' research on landscapes of leisure in the countryside, primarily in 1930s and 1940s England, examined how landscape was entwined with senses of citizenship and used as a method to 'improve' the citizen arguing that "always...the good citizen made sense only in relation to a contrasting 'anti-citizen'” (1997, 142). Similarly, Ruth Lister et al. discuss how ideas of 'good' and 'bad' citizens were continually referred to by young people in their research on contemporary understandings of citizenship. Whereas 'bad' citizens were defined as "selfish, uncaring, lazy and lacking in respect”, a 'good' citizen would, in the words of one participant, "keep the country clean and that; help old people across the road, things like that” (2003, 244, 247).

For both Matless and Lister et al. therefore, we can see how similar ideas about behaviour have been used as frameworks for understanding citizenship. Becoming a Scout 
also involved conforming (or appearing to conform) to certain types of behaviour and a series of expectations both inside and outside of scouting spaces. In many ways, this construction is comparable with constructions of 'ideal childhoods' and how institutions or adults attempt to mould particular types of behaviour or beliefs from young people within their care (James and Prout 1997; Kraftl 2006). I now wish to draw on two key features of scouting in order to illustrate these moral geographies: the Scout Law and Scout Badges. These examples also demonstrate the paper's broader argument about the way in which Boy Scouts were afforded responsibilities as active citizens despite their youthfulness.

\section{The Scout Law}

At Investiture - the ceremony that transforms an individual 'into' a Scout when they join the organisation - a young person makes the following verbal declaration: "On my Honour, I Promise to do my best, To do my Duty to God and the Queen, To help other people, And to keep the Scout Law.” This Scout Promise would then be repeated at various ceremonies and is often seen as the most sacred part of scouting philosophy, embodying the three elements of Baden-Powell's citizenship model. The Scout Law to which it refers is a useful example of how young members were also fixed into a moral framework of good citizenship. Although each national association has developed their own Scout Law, the majority have remained true to the original in Scouting for Boys:

\section{A Scout's Honour is to be Trusted}

2. A Scout is Loyal to the King, and to his officers, and to his country and to his employers.

3. A Scout's Duty is to be Useful and to Help Others

4. A Scout is a Friend to All, and a Brother to every Other Scout, No Matter What Social Class the Other Belongs

5. A Scout Is Courteous

6. A Scout is a Friend to Animals 
7. A Scout Obeys Orders of his patrol leader or scout master without question.

8. A Scout Smiles and Whistles under all circumstances

9. A Scout is Thrifty. (Baden-Powell 2004 [1908], 44)

These laws stressing obedience, loyalty and duty functioned as a code of conduct and were a popular way of simplifying (adult) messages and governing behaviours in a communicable form, similar to the Country Code (Merriman 2005) and the Youth Hostels Association membership laws (Matless 1998, 72-3).

The notion of 'living up to' the Scout Law was strongly advocated by the organisation, often through providing examples of immoral youth 'without' law. This dichotomy can be seen in a fictional exchange in Rivals of Parnham where Eric Ames the Scout is arguing with gang leader Dizzy:

Ames shook himself free of Dizzy's arm. 'I came to tell you that I won't do as you ask,' he said spiritedly. 'I'm a Scout, and though I haven't been properly enrolled yet, I've got to live up to the laws.' Dizzy laughed coarsely. 'You don't believe in that silly rot - that's only for saps. Real blokes don't want no laws laid down for them. They make their own laws.

'You say that because - well - because you couldn't live up to any decent laws,' Eric said. (Dimmock 1939, 18)

Although the Scout Law could be viewed as a suggestive code of conduct with no real repercussions, there have been clear examples where certain types of behaviour, or beliefs, have been judged 'unlawful' by the organisation and members excluded on these grounds. For example, a minority of Boy Scouts were exposed as members of the Young Communist League in the 1950s and castigated for their failure to ‘keep’ the Scout Law (Mills 2011b).

The Scout Law was communicated to members through distinct practices and everyday performances. For example, the shorter Cub Scout Law - “A Cub Scout always does his best, thinks of others before himself and does a Good Turn every day" - uses the 
'good turn' as a practical application of the Law for younger members. This daily act of kindness to help another person, such as those illustrated in Plate 3, was a habitual performance of scouting identity and citizenly duty.

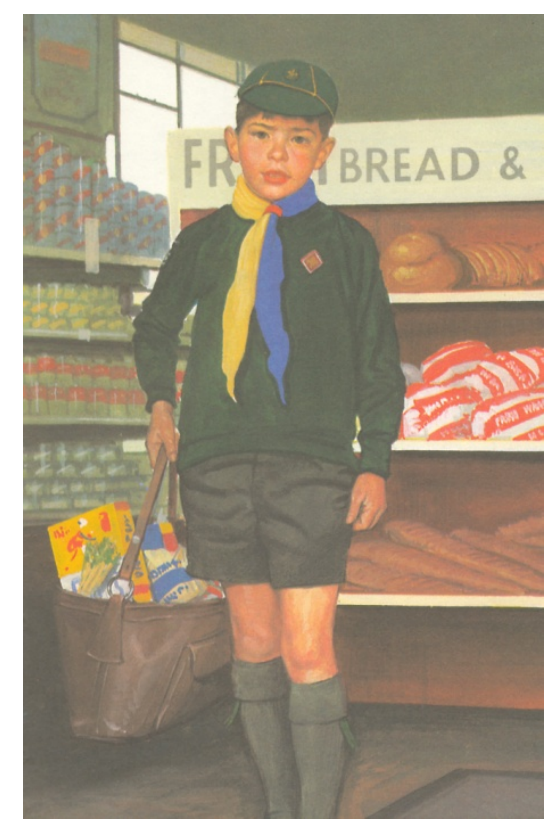

Plate 3: 'A Cub Scout does a Good Turn by collecting groceries for an elderly person' Source: Cub Scouts: A Ladybird Book

Copyright (C) Ladybird Books Ltd, 1970

Reproduced by permission of Ladybird Books Ltd

In outlining the importance of the 'good turn', Baden-Powell again turned to historic tales of heroism:

You scouts cannot do better than follow the example of your forefathers, the knights...every day they had to do a good turn to somebody, and that is one of our rules. When you get up in the morning...tie a knot in your handkerchief or necktie...to remind yourself of it; and when you go to bed at night think who you did the good turn to. (Baden-Powell 2004 [1908], 23)

I would argue that the temporal aspect of completing a good turn every day, and using a material aide to remember, was important in encouraging citizenly-like behaviours outside of set scouting times and spaces, whether in the home, street or neighbourhood. 
Through mechanisms such as the 'good turn', Scouts became emblematic of the good, law-abiding, young citizen and this public image meant that members, and more broadly the organisation, began to represent certain values and expectations. Consequently, there were often criticisms voiced directly to Baden-Powell from certain members of the public who had encountered 'bad' Boy Scouts. For example, this request from the secretary of the King George and Queen Mary Club for Overseas Forces in 1918 reads:

We feel we would like to convey to you how disappointing some of the boys are on occasions when we would expect more from them than others. For instance, continually lately in the undergrounds and in buses, women give up their seats to crippled soldiers or old women with babies while Boy Scouts sit...it is a bad example, and if they could hear what people think they would not be flattered. ${ }^{4}$

These types of criticism reflect the perceived 'risk' of 'bad ambassadors' for scouting and broader tensions around class in the Scout Movement. Ideas about 'scout-like' behaviour can also be seen in the instruction booklets later designed for Scouters, stressing their role as adult instructors in moulding the right-type of Boy Scout:

When a Scout in uniform carries out a small act of service in public, observers will say to themselves: 'Good types, these Boy Scouts.' If another Scout were to throw his weight about, barge his way to the head of a bus queue, bag a seat and leave a lady standing, the rest of the passengers could not be blamed for thinking the worst about Scout training. (Wood 1970, 6)

The physical appearance of a Scout was also seen as important in maintaining the organisation's reputation:

A Senior Scout may be kind, helpful, trustworthy and all the rest but if he went around with unkempt hair, in a scruffy uniform with shorts turned three parts up his thighs, beret on the back of head and shuffling along with hands in pockets (and I'm sorry to say I've seen a few types knocking about the streets of London and at seaside resorts during the holiday season) members of the public would undoubtedly think: “Some Scout! The Movement isn’t what it was”. (Wood 1970, 7) 
Here, 'scruffy' Scouts are positioned in particular geographical spaces - urban London and 'brash' seaside resorts - locations infused with class-based stereotypes. Overall then, we can see how a moral landscape of youth citizenship and ideas on behaviour were communicated through the Scout Law. Furthermore, it was translated as a series of embodied performances required to maintain the commitment of Scouts outside the time-spaces of scouting, as well as uphold the reputation of the movement.

\section{Scout Badges}

The second example of a key feature that illustrates the moral geographies of scouting and this paper's broader argument about youth citizenship are Scout badges. These fabric patches designed to be sewn onto uniforms each represented achievement in a scouting skill, for example first-aid or fire-lighting. Here, I discuss how badges represented sets of knowledge that model 'citizen-scouts' were seen to need, and in addition, how various material objects such as badges, record cards and uniform were utilised to achieve its aims. There are obvious similarities here with school in terms of a programme of learning repeated annually and exams marked by an adult 'expert'. However, aptitude in scouting was rewarded with a badge rather than formal qualification and the education of Scouts was always seen in the context of the movement's ideological aims as part of its citizenship training. We can also see how scout badges tapped into ideas of children's competitiveness and desire to collect 'stuff', as well as the role of competition more broadly in educational settings (Ploszajska 1996; Gagen 2004).

Original badges echoed teachings from Scouting for Boys. For example, ideas of the healthy (masculine) body and physical strength can be seen in the requirements to earn the 'Athlete' badge and one requirement of the early 'Tenderfoot' badge was to learn the 
meaning of the Union Jack; learning to be a scout involved learning to be a citizen and viceversa. Over time, the names and criteria of badges have changed to reflect new technologies and leisure activities, yet core sets of knowledge that mirror the organisation's vision of a good young citizen have remained. For example, the requirements of the later Cub Scout Bronze Arrow Badge required a boy to know several distinct sets of information, including "how and why he should keep his teeth, hands and nails clean”, "the whereabouts of essential services such as: fire station, telephone, bus stops, railway station, post office, doctor” and "the first verse of the National Anthem" (Harwood 1970, 34). The common themes running through these requirements (patriotism, physical ability, knowledge of local services) illustrates the attributes scouting authorities felt its young members ought to know. Completing this skill set in the presence of an adult observer was then rewarded with a badge, but more broadly, meant that the individual was seen as 'useful' in the eyes of the Movement, particularly in an emergency, depicted here in Plate 4:

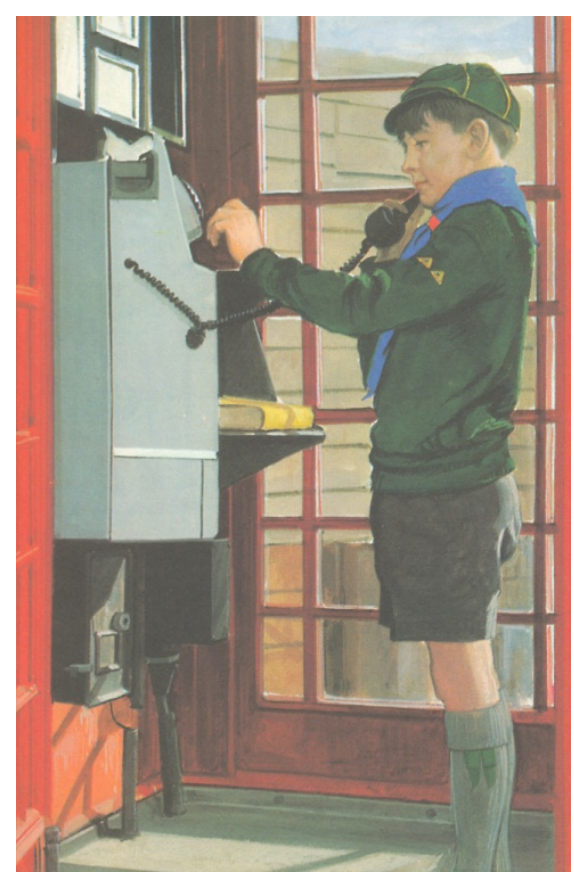

Plate 4: 'Using a public telephone in an emergency' Source: Cub Scouts: A Ladybird Book Copyright (C) Ladybird Books Ltd, 1970 Reproduced by permission of Ladybird Books Ltd 
Indeed, the successful demonstration of this specific practice of using a public telephone feeds into broader understandings about the skills and aptitude that could be 'expected' from a Boy Scout when needed by a neighbour or parent (and by extension, the nation or empire). The badge requirements also show how Boy Scouts were afforded responsibilities as active citizens despite their age. Training in these skills was seen by Baden-Powell as crucial to instilling senses of active citizenship and for Boy Scouts to be able, as well as prepared, to perform whatever was asked of them.

Badges also provided another opportunity for the organisation to communicate ideas about appropriate behaviours in addition to the Scout Law. This can be seen in the instructions for those responsible for examining scout badges. For example, the First Class Scout Test was assessed through a physical incident hike and a written log-book. The accompanying assessors manual states:

The Log will also tell him [examiner] a great deal about less tangible things; about the boy as a person, whether or not he is maintaining good scouting standards in his life, ...courtesy, good manner, smartness, and so on...It is to be feared that sometimes Scouts unconsciously give themselves away in a bad light in their Logs. Not all these cases are as extreme as the one mentioned... who produced a wonderful Log and then marred it with the final sentence:

"Arrived at the station. We told the booking-clerk we were still under 14, so we were able to travel at half-fare, which saved us a shilling each"

Quite properly, that boy did not pass his test. (Newcombe 1963, 6)

Here, a recorded incident of 'bad' behaviour resulted in an overall failure, despite the individual displaying proficiency in all other areas of the Test. We can therefore see the parameters of 'good' and 'bad' scouting as expected by the authorities, even in the routine and banal performances of working towards a badge. 
As mentioned earlier, competitiveness was a central theme in the performance of scouting and its use of badges. Advertised competitions in the organisation's magazine were also used by the BSA to reward specific sets of knowledge. For example, in 1922 a tour in Belgium was on offer for those able to list the six principal uses of a Scout staff. ${ }^{5}$ As well as the correct answers, Baden-Powell suggested to the Editor of The Scout that a letter of recommendation by a Scouter was also needed "to ensure that the boy is a good Scout", illustrating the way in which good behaviour was valued just as much as scouting knowledge. ${ }^{6}$ Overall, we can see how tests and scout badges were useful tools in communicating ideas about the moral boundaries of scouting citizenship. However, as this extract from a junior Scout novel shows, a 'higher reward' was often advocated:

'You're making a fine Scout, Eric, and I'm jolly proud to have you in my Patrol.' I saw Eric’s eyes glisten.

'You really mean that, Dennis?' he said eagerly.

'I do. You know, old chap, scouting is something more than just passing badges though badges are grand things to work for, and don't forget it. Scouting teaches a chap to use his head, to think before he acts, to use common sense. (Dimmock 1939, 82-3)

This exchange shows the perceived wisdom of the older Scout, as well as reinforcing messages about the wider aims of scouting that supersede material badges.

The two examples of the Scout Law and Scout badges in this section have both demonstrated how ideas of usefulness and 'good' behaviour combined in a powerful moral geography that had youth citizenship at its core. In particular, both examples stressed the potential Scouts had to be active citizens in their everyday lives, whether through 'good turns' or recalling skills previously learnt in badge-work, and in doing so, performing the roles laid out for them by the organisation. 


\section{Conclusion}

This paper has explored how youth citizenship was employed and enacted in the Scout Movement. In doing so, it has made three specific contributions. First, it has expanded work on the geographies of youth citizenship to consider alternative spaces in civil society alongside state-level citizenship education in schools. It has provided a historical example of citizenship training, demonstrating how Baden-Powell's scheme cast young people as both 'citizens-in-the-making' - preparing them for adult citizenry - as well as giving them a distinct set of responsibilities as 'active citizens' whilst Scouts. Second, the paper has offered a rare and much-needed historical perspective within children's geographies. In exploring how a distinct set of characteristics were seen as essential to the construction of a model Boy Scout and used to communicate the ideals and ambitions of Baden-Powell's project, it has shown that questions over goodness, morality and futures in the context of young people are both geographical and historically situated. Indeed, the sub-discipline of children's geographies could benefit from more research that considers how ideas on childhood and youth have emerged and shifted over time. Finally, the paper has provided an empirical example of what embodied historical geographies might look like, arguing that archival methods (and seriously considering objects as part of the archive) can bring additional insight into the lived experiences of young people and the institutions that sought to shape their lives.

In this conclusion, I want to briefly reflect on how 'citizen-scout' has been reenvisioned or re-articulated over time and discuss the ways in which a geographical perspective could contribute to understanding youth movements. The original 'model' Scout laid out in the formative years of scouting and explored in this paper has been used as a barometer to judge scouting behaviours and personalities throughout the Movement's history; most notably during times of tension and change in its membership and responses to social 
difference. Indeed, despite the cohesive rhetoric and mechanisms analysed in this paper, Scouts were still divided by struggles, whether political, religious or gendered, about belonging and acceptance. Furthermore, in defining the ideal 'Scout', Baden-Powell subsequently defined who could not be a Scout through its membership criteria - for example girls or atheists. These ideas, however, have been subverted and transgressed over time by young people and their own 'acts' of citizenship - whether through circumnavigating the institutional system, enlisting local adult Scouters to permit them into the organisation, or defiantly 'scouting on regardless' (Mills 2011a). Whilst the organisation might be viewed as a stable, bounded space where Scouts play out prescribed identities, I argue it is a more fluid ensemble of individuals, knowledges and materialities that function in producing particular subjectivities around youth.

In terms of scouting's relationship with citizenship, there have been a number of policy shifts, encompassed in contemporary scouting practise, that reflect broader changes in British society. These have been framed around gender (moving towards mixed sex scouting), religion (changes in uniform and the Scout Promise) as well as broader developmental strategies to modernise and compliment young people's lives (increasing focus on sustainability, shifts in age-range sections to tie into school leaving ages). Whilst the organisation's rhetoric on citizenship has always made reference to 'active' citizens, scouts have also been encouraged to be 'moral', 'British', 'effective', 'sustainable' and various other 'brands' of citizens at different points in time. For example, the current aim of the organisation in the UK is "to promote the development of young people in achieving their full physical, intellectual, social and spiritual potential, as individuals, as responsible citizens and as members of their local, national and international communities” (Scout Association 2011). Indeed, many of their central tenets have been re-packaged to mirror the various 
'hyphenated' brands of citizenship (multicultural, democratic, global, cosmopolitan) that reflect broader extensions in the concept beyond the nation-state (Desforges et al. 2005).

One can therefore see how the philosophies and practices of youth movements are part of a broader state project concerned with notions of youth citizenship and nationhood. There is scope, therefore, for geographers to examine in more detail the relationship between the state and civil society in the context of youth citizenship and how, as this paper hinted, competing and shifting conceptions of 'good' citizenship are played out and refracted in both of their activities. Overall, I contend that a geographical approach to the study of youth movements can more fully excavate the role of spaces, practices and embodied cultures in the performance of these youth work arenas. Indeed, this is just one example of how a youth movement was accomplished and achieved as an institutional space through specific moral geographies and various processes, strategies and regulations. There is clearly further scope to explore the complex historical geographies of education and youth citizenship through examining other diverse arenas of learning such as boys’ and girls' clubs, religious schemes, language organisations, and political youth-wings, in order to understand the specific dimensions and characteristics of youth citizenship and informal education over time.

\section{References}

Baden-Powell R 1922a Rovering to Success Herbert Jenkins, London

Baden-Powell R 1922b Jamboree (January) Boy Scout Association, London

Baden-Powell R 1944 [1919] Aids to Scoutmastership World Brotherhood Edition, Boy Scouts of America, New York

Baden-Powell R 2004 [1908] Scouting for Boys: A Handbook for Instruction in Good Citizenship Oxford University Press, Oxford

Boehmer E 2004 Introduction and Notes on Scouting for Boys in Baden-Powell R Scouting for Boys Oxford: Oxford University Press, xi-xxxix.

Boy Scouts Association (dir) 1917 Be Scouts - Be Prepared! [film] Boy Scouts Association, London 
Cabinet Office 2010 National Citizen Service

(http://www.cabinetoffice.gov.uk/news/national-citizen-service-introduced) Accessed 2 June 2011

Cobb N 2007 Governance through Publicity: Anti-social Behaviour Orders, Young People, and the Problematization of the Right to Anonymity Journal of Law and Society 34 342-73

Cockburn T 1998 Children and citizenship in Britain: a case for a socially independent model of citizenship Childhood 599-117

Cohen S 1973 Folk Devils and Moral Panics Granada Publishing Limited, St Albans

Collins D and Coleman T 2008 Social geographies of education: looking within, and beyond, school boundaries Geography Compass 2 281-299

Cresswell T 1996 In place/out of place: geography, ideology, and transgression University of Minnesota Press, London; Minneapolis

Davidson H B 1926 Peter Lawson, Wolf-Cub or the Mystery of Redcroft Farm Bright Books, London

Davies B 1999 From Voluntaryism to Welfare State: A History of the Youth Service in England. Volume 1:1939-1979 Youth Work Press, Leicester

DeLyser D, Sheehan R and Curtis A 2004 eBay and research in historical geography Journal of Historical Geography 30 764-782

Desforges L, Jones R and Woods M 2005 New Geographies of Citizenship Citizenship Studies 9 439-451

Dimmock F H 1939 Rivals of Parnham Boy Scouts Association, London

Dimmock F H 1954 Scout Family Robinson Ward, Lock \& Co Ltd, London; Melbourne

Driver F 1988 Moral Geographies: Social Science and the Urban Environment in Mid-

Nineteenth Century England Transactions of the Institute of British Geographers 13 275-287

Foucault M 1988 Technologies of the self in Martin L H, Gutman H and Hutton P H eds Technologies of the Self Tavistock, London 16-49

Freeden M 2003 Civil Society and the Good Citizen: Competing Conceptions of Citizenship in Twentieth-century Britain in Harris $\mathbf{J}$ ed Civil Society in British History: Ideas, Identities, Institutions Oxford University Press, Oxford 275-291

Gagen E A 2000 An example to us all: child development and identity construction in early 20th-century playgrounds Environment and Planning A 32 599-616

Gagen E A 2001 Too good to be true: representing children's agency in the archives of playground reform Historical Geography 29 53-64

Gagen E A 2004 Making America flesh: physicality and nationhood in early twentieth century physical education reform Cultural Geographies 11 417-442 
Gagen E A, Lorimer $\mathbf{H}$ and Vasudevan A eds 2007 Practising the Archive: Reflections on Methods and Practice in Historical Geography Historical Geography Research Series 40 Royal Geographical Society/IBG, London

Griffin C J and Evans A B 2008 Historical Geographies of Embodied Practice and Performance Historical Geography 36 5-162

Gruffudd P 1996 The countryside as educator: schools, rurality and citizenship in inter-war Wales Journal of Historical Geography 22 412-423

Hall S and Jefferson T eds 1976 Resistance Through Rituals: Youth Subcultures in Post-war Britain Hutchinson, London

Hanson Thiem C 2009 Thinking through education: the geographies of contemporary educational restructuring Progress in Human Geography 33 154-173

Harwood D 1970 Cub Scouts: Who they are and what they do Ladybird, Loughborough

Heater D 2001 The history of citizenship education in England The Curriculum Journal 12 103-123

Isin E F 2002 Being Political: Genealogies of Citizenship University of Minnesota Press, Minneapolis

James A 1986 Learning to belong: the boundaries of adolescence in Cohen A P ed Symbolising Boundaries: identity and diversity in British cultures Manchester University Press, Manchester 155-170

James A and Prout A 1997 Constructing and Reconstructing Childhood Routledge, London Jeal T 1991 Baden-Powell London: Pimlico

Jeffs T 2005 Citizenship, youth work and democratic renewal, The Encyclopaedia of Informal Education, www.infed.org/association/citizenshp_youth_work_democratic_renewal.htm Accessed 2 June 2011

Katz C 2008 Childhood as spectacle: relays of anxiety and the reconfiguration of the child Cultural Geographies 15 5-17

Kearns A 1992 Active Citizenship and Urban Governance Transactions of the Institute of British Geographers 17 20-34

Kearns A 1995 Active Citizenship and local governance: political and geographical dimensions Political Geography 14 155-75

Kraftl P 2006 Building an idea: the material construction of an ideal childhood Transactions of the Institute of British Geographers 31 488-504

Kraftl P 2008 Young people, hope and childhood-hope Space and Culture 11 81-92 
Kyle R G 2007 Moral Geographies of The Boys’ Brigade in Scotland, Unpublished PhD Thesis, School of Geographical and Earth Sciences, University of Glasgow

Lister R, Smith N, Middleton S and Cox L 2003 Young People Talk about Citizenship: Empirical Perspectives on Theoretical and Political Debates Citizenship Studies 7 235-253

Lorimer H 2009 Caught in the nick of time: archives and fieldwork in Aitken S, Crang M, DeLyser D, Herbert S and McDowell L eds The SAGE Handbook of Qualitative Geography Sage, London 248-272

Marshall T H 1950 Citizenship and Social Class and other Essays Cambridge University Press, Cambridge

Matless D 1995 The Art of Right Living: landscape and citizenship, 1918-39 in Thrift N and Pile S eds Mapping the Subject: geographies of cultural transformation Routledge, London 93-122

Matless D 1997 Moral Geographies of English Landscape Landscape Research 22 141-155

Matless D 1998 Landscape and Englishness Reaktion Books Ltd, London

Merriman P 2005 'Respect the life of the countryside': the County Code, government and the conduct of visitors to the countryside in post-war England and Wales Transactions of the Institute of British Geographers 30 336-350

Milligan C and Fyfe N R 2005 Preserving space for volunteers: exploring the links between voluntary welfare organisations, volunteering and citizenship Urban Studies 42 417-433

Mills S 2011a Scouting for Girls? Gender and the Scout Movement in Britain Gender, Place and Culture 18 537-556

Mills S 2011b Be Prepared: Communism and the Politics of Scouting in Britain Contemporary British History 25 429-450

Mills S 2009 Citizenship and Faith: Muslim Scout Groups in Phillips R ed Muslim Spaces of Hope: Geographies of Possibility in Britain and the West Zed Books, London 85-103

Mitchell K 2003 Educating the national citizen in neoliberal times: from the multicultural self to the strategic cosmopolitan Transactions of the Institute of British Geographers 28 387403

Mische A 1996 Projecting Democracy: The Formation of Citizenship Across Youth Networks in Tilly C ed Citizenship, Identity and Social History Cambridge University Press, Cambridge 131-158

Moore F P L 2010 Tales from the archive: methodological and ethical issues in historical geography research Area 42 262-270

Newcombe N W 1963 Setting The First and Second Class Journeys Boy Scouts Association, London

Painter J 2006 Prosaic geographies of stateness Political Geography 25 752-774

Phillips R 1997 Mapping Men and Empire: A Geography of Adventure Routledge, London 
Ploszajska T 1996 Constructing the subject: geographical models in English schools, 18701944 Journal of Historical Geography 22 388-398

Ploszajska T 1998 Down to earth? Geography fieldwork in English schools, 1870-1944 Environment and Planning D: Society and Space 16 757-774

Proctor T M 2002 On My Honour: Guides and Scouts in Interwar Britain American Philosophical Society, Philadelphia

Proctor T M 2009 Scouting for Girls: A Century of Girl Guides and Girl Scouts Praeger, Santa Barbara, CA; Denver, CO; Oxford, England.

Pykett J 2009 Making Citizens in the Classroom - An Urban Geography of Citizenship Education? Urban Studies 46 803-823

Rose D 2005 The world of the Jewish youth movement The Encyclopaedia of informal education, www.infed.org/informaljewisheducation/jewish_youth_movements.htm Accessed 2 June 2011

Rose N 1996 Identity, Genealogy, History in Hall S and DuGay P eds Questions of Cultural Identity Sage, London 128-51

Savage J 2007 Teenage: The prehistory of Youth Culture 1875-1945 Penguin, London

Scout Association 2011 Scouting in the United Kingdom

(http://scouts.org.uk/cms.php?pageid=1828) Accessed 28 April 2011

Springhall J 1977 Youth, Empire and Society: British Youth Movements 1883-1940 Croom Helm, Beckenham

Stachura P 1981 The German Youth Movement 1900-1945 An Interpretive and Documentary History Palgrave Macmillan, London

Thomson R, Holland J, McGrellis S, Bell R, Henderson S and Sharpe S 2004 Inventing adulthoods: A biographical approach to understanding youth citizenship Sociological Review 52 218-239

Valentine G 2003 Boundary crossings: transitions from childhood to adulthood Children's Geographies 1 37-52

Valentine G 1996 Angels and Devils: moral landscapes of childhood, Environment and Planning D: Society and Space 14 584-599

Van Hoven B and Hörschelmann K 2005 Spaces of Masculinities London: Routledge

Warren A 1986 Citizens of empire - Baden-Powell, Scouts and Guides and an Imperial ideal 1900-1940 in Mackenzie J ed Imperialism and Popular Culture Manchester University Press, Manchester

Weller S 2007 Teenagers’ Citizenship: Experiences and Education Routledge, London 
Wilkinson P 1969 English Youth Movements 1908-1930 Journal of Contemporary History 4 3-23

Wittemans S 2009 The Double Concept of Citizen and Subject at the Heart of guiding and scouting in Block N R and Proctor T M eds Scouting Frontiers: Youth and the Scout Movement's First Century Cambridge Scholars Publishing, Cambridge 56-71

Wood E G W (1970) Tellling the Public Boy Scouts Association, London

\section{Notes}

\footnotetext{
${ }^{1}$ The organisation changed to 'The Scout Association' in 1967.

2 Scout Association Archive (hereafter SAA)/TC/244A/Histories/Groups and Districts/10 ${ }^{\text {th }}$ Brighton Scout Group/Boy Scout Diary

${ }^{3}$ SAA/TC/244A/Histories/Groups and Districts/10 ${ }^{\text {th }}$ Brighton Scout Group/Boy Scout Diary

${ }^{4}$ SAA/TC/432/Criticisms, Correspondence, Secretary of the King George and Queen Mary Club for Overseas Forces to Robert Baden-Powell, 19 February 1918

${ }^{5}$ SAA/TC/43/Competitions/‘Holiday Abroad Competition’, 1922

${ }^{6}$ SAA/TC/43/Competitions, Correspondence, Robert Baden-Powell to F. Haydn Dimmock, 3 February 1922
} 